\title{
連続消音エルボの音響減衰について \\ ON SOUND ATTENUATION OF DOUBLE LINED ELBOWS
}

\author{
板本守正*, 塩川博 義**, 浦田香 織*** \\ Morimasa ITAMOTO, Hiroyoshi SHIOKAWA and Kaori URATA
}

\begin{abstract}
Sound attenuation data of double lined elbows to be used for acoustic design in air duct systems are few, so the total of sound attenuation values for two single lined elbows is generally used.

In this paper, for evaluating sound attenuation of double lined elbows, insertion loss values for 37 kinds of double lined elbows are measured. They are formed from three combinations for two single lined elbows, three kinds of connection directions and seven kinds of duct lengths between the two elbows. Those insertion loss values measured are compared with the total of sound attenuation values for two single lined elbows.
\end{abstract}

Keywords: Air duct systems, Double lined elbows, Sound attenuation, Insertion loss ダクト系, 連続消音エルボ, 音響減主, 㨂入損失

\section{1. 緒言}

わが国では，ダクト内を通過する騒音を減衰させるために消音エ. ルボを用いる場合が多い。また，消音エルボ１個では十分な音響減 衰が得られない場合, 消音エルボを連続して用いることが考えられ る。連続したエルボの損失圧力については，伊藤 "および佐藤 ${ }^{2} に$ より系統的な研究が行なわれている。そ㧈によ扎ば，連続エルボの 損失圧力は 2 つの単体エルボのそ扎らを加算した值にはならない。 連続エルボの音響減衰については, Lippert ${ }^{33}$, 勝田・後藤 ”およ び寺尾うなどにより, 連続消音エルボの音響減衰については, 根来・

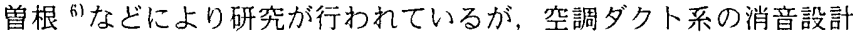
に用いることができる音響减衰量のデータはほとんどない。そのた め，実際の空調ダクト系における消音設計で用いら扟る連続消音工 ルボの音響减衰量は，2つの単体消音エルボのそ㧈らを加算したも のを用いるのが現状である。しかし，連続消音エルボの音響減衰量 が 2 つの単体消音エルボのそれらを加算した值となるかどうかは明 確でない。

そこで，空調ダクト系の消音設計用データの体系化をはかるため に，本実験では 2 種類の消音エルボを用いて 3 種類の連続消音エル ボの組合せを作り; 接続方向を 3 方向およびエルボ間のダクトの長
さを変化させて,それぞれの連続消音エルボの音響減衰量を求めた。 また, それらと $2 つ の$ 単体消音エルボの音響減衰量を加算した值と を比較検討したので，その結果を報告する。

\section{2. 供試体の種類}

消音エルボを図 1 に示す。消音エルボは断面寸法 $600 \times 600 \mathrm{~mm}$ の El bow A と，断面寸法 $600 \times 600 \mathrm{~mm}$ でスプリッタ・ベーン付きの El bow As の 2 種類で，いずれも内部吸音体は，背後に空気層 $50 \mathrm{~mm}$ を有す る厚さ $50 \mathrm{~mm}$, 密度 $32 \mathrm{~kg} / \mathrm{m}^{3}$ のグラス・ファイバで構成されている。 図 2 に連続消音エルボの接続方向を示す。 $0^{\circ}$ 方向は $S$ 字型, $90^{\circ}$ 方向は好じれ $S$ 字型, $180^{\circ}$ 方向はU 字型である。

また，その組合せは，A+A，AstAおよびAtAsの 3 通りである。

表 1 に供試体の表記方法を定義する。一例を挙げると, 供試体「 $0^{\circ}$ -AA-0」は消音エルボの接続方向が $0^{\circ}$ ，消音エルボの組合せが $\mathrm{A}+\mathrm{A}$, 消音エルボ間のダクトの長さが $0 \mathrm{~mm}$ であることを示す。

3、実験装置および方法

$3-1$. 単体消音エルボ

実験装置は図 3 に示すダクト系 (a) と（b)とを用いる。いずれもス

\footnotetext{
本諭文は日本建築学会大会において発装した文献》10のの内容を再検討し，まとめ植したものである。

* 日本大学生産工学部建築工学科 教授.工博 Prof., Dept. of Architectural Engineering, College of Industrial Technology, Nihon

** 日本大学生産工学部建築工学科 助教授 $\cdot$ 工博 Univ., Dr. Eng.

Assoc. Prof., Dept. of Architectural Engineering, College of Industrial Technology, Nihon Univ., Dr. Eng.

*** 日本大学生産工学部建築工学科 副手

Research Assoc., Dept. of Architectural Engineering, College of Industrial Technology, Nihon Univ.
} 
表 1 供試体の種穎

\begin{tabular}{|c|c|c|c|}
\hline Test unit & Connection & Combination & $\mathrm{L} .[\mathrm{mm}]$ \\
\hline $0^{\circ}-\mathrm{AA}-$ & $0^{\circ}$ & $\overline{A+A}$ & 0 \\
\hline $0^{\circ}-A A-600$ & $0^{\circ}$ & $A+A$ & 600 \\
\hline $0^{\circ}-A A-900$ & $0^{\circ}$ & $A+A$ & 900 \\
\hline $0^{\circ}-A \quad A-1300$ & $0^{\circ}$ & $A+A$ & 1300 \\
\hline $0^{\circ}-\mathrm{A} A-1700$ & $0^{\circ}$ & $A+A$ & 1700 \\
\hline $0^{\circ}-A \quad A-2000$ & $0^{\circ}$ & $A+A$ & 2000 \\
\hline $0^{\circ}-\mathrm{A} A-2400$ & $0^{\circ}$ & $A+A$ & 2400 \\
\hline $0^{\circ}-A s A-0$ & $0^{\circ}$ & As $+A$ & 0 \\
\hline $0^{\circ}-A s A-600$ & $0^{\circ}$ & As $+A$ & 600 \\
\hline $0^{\circ}-A s A-900$ & $0^{\circ}$ & $A s+A$ & 900 \\
\hline $0^{\circ}-$ AsA -1300 & $0^{\circ}$ & $\mathrm{As}+\mathrm{A}$ & 1300 \\
\hline $0^{\circ}-$ AsA -2400 & $0^{\circ}$ & As $+A$ & 2400 \\
\hline $0^{\circ}-\mathrm{A} A \mathrm{As}^{-} \quad 0$ & $0^{\circ}$ & $A+A s$ & 0 \\
\hline $0^{\circ}-\mathrm{A} A s-600$ & $0^{\circ}$ & $A+A s$ & 600 \\
\hline $0^{\circ}-\mathrm{A} A \mathrm{~s}-900$ & $0^{\circ}$ & $A+A s$ & 900 \\
\hline $0^{\circ}-\mathrm{A}$ As -1300 & $0^{\circ}$ & $A+A s$ & 1300 \\
\hline $0^{\circ}-\mathrm{A} A \mathrm{As}-2400$ & $0^{\circ}$ & $A+A s$ & 2400 \\
\hline $90^{\circ}-\mathrm{A} A-$ & $90^{\circ}$ & $A+A$ & 0 \\
\hline $90^{\circ}-\mathrm{AsA}-$ & $90^{\circ}$ & As $+A$ & 0 \\
\hline $90^{\circ}-\mathrm{A} \mathrm{As}^{-}$ & $90^{\circ}$ & $A+A s$ & 0 \\
\hline $180^{\circ}-\mathrm{AA}-0$ & $180^{\circ}$ & $A+A$ & 0 \\
\hline $180^{\circ}-\mathrm{A} A-600$ & $180^{\circ}$ & $A+A$ & 600 \\
\hline $180^{\circ}-A A-900$ & $180^{\circ}$ & $A+A$ & 900 \\
\hline $180^{\circ}-\mathrm{A} A-1300$ & $180^{\circ}$ & $A+A$ & 1300 \\
\hline $180^{\circ}-\mathrm{A} A-1700$ & $180^{\circ}$ & $A+A$ & 1700 \\
\hline $180^{\circ}-\mathrm{A} A-2000$ & $180^{\circ}$ & $A+A$ & 2000 \\
\hline $180^{\circ}-\mathrm{A} A-2400$ & $180^{\circ}$ & $A+A$ & 2400 \\
\hline $180^{\circ}-\mathrm{AsA}-0$ & $180^{\circ}$ & As $+A$ & 0 \\
\hline $180^{\circ}-A s A-600$ & $180^{\circ}$ & As $+A$ & 600 \\
\hline $180^{\circ}-$ AsA -900 & $180^{\circ}$ & As $+A$ & 900 \\
\hline $180^{\circ}-$ AsA -1300 & $180^{\circ}$ & As $+A$ & 1300 \\
\hline $180^{\circ}-$ AsA -2400 & $180^{\circ}$ & As $+A$ & 2400 \\
\hline $180^{\circ}-\mathrm{A} \mathrm{As}^{-} \quad 0$ & $180^{\circ}$ & $A+A s$ & 0 \\
\hline $180^{\circ}-\mathrm{A}$ As -600 & $180^{\circ}$ & $A+A s$ & 600 \\
\hline $180^{\circ}-\mathrm{A}$ As -900 & $180^{\circ}$ & $A+A s$ & 900 \\
\hline $180^{\circ}-$ As -1300 & $180^{\circ}$ & $A+A s$ & 1300 \\
\hline $180^{\circ}-$ A As -2400 & $180^{\circ}$ & $A+A s$ & 2400 \\
\hline
\end{tabular}

L: Duct length between two elbows
ピーカから $1 / 1$ オクターブ・バンド・ノイズを発生させ, 残偣室内 平均音圧レベルを測定する。消音エルボの挿入損失はダクト系 (b) の残響室内平均音圧レベルからダクト系 (a)のそ扎を減じて求める。 なお，各ダクト系ともスピーカへの入力電圧は等しくしてある。

\section{$3-2$. 㖶続消音エルボ}

実験装置は図 3 に示すダクト系 $(\mathrm{c})$ と (d)～( f ) とを用いる。いずれ もスピーカから $1 / 1$ オクターブ・バンド・ノイズを発生させ，残䇾 室内平均音压レベルを測定する。連続消音エルボの挿入損失はダク 卜系 (d)〜 (f)の残響室内平均音圧レベルからダクト系 (c)のそれを 減じて求める。なお，連続消音エルボ接続方向の $90^{\circ}$ は実験室の関 係により，エルボ間距離 $0 \mathrm{~mm}$ のみ測定を行った。また，各ダクト系と もスピーカへの入力電圧は等しくしてある。
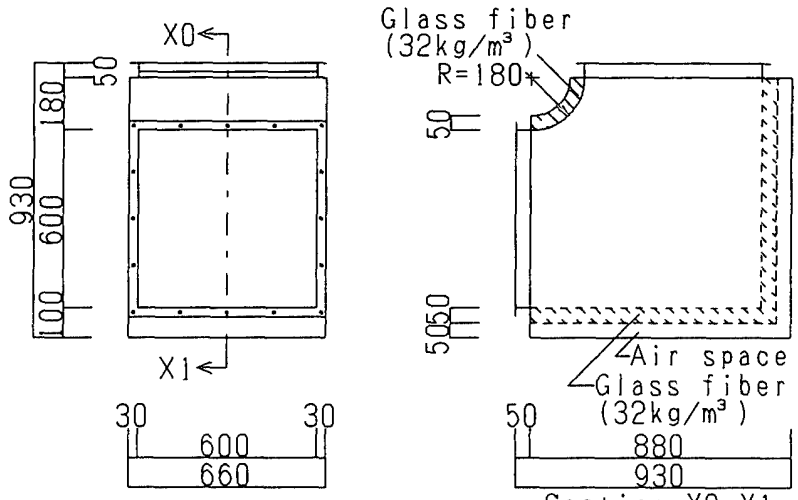

Elbow A
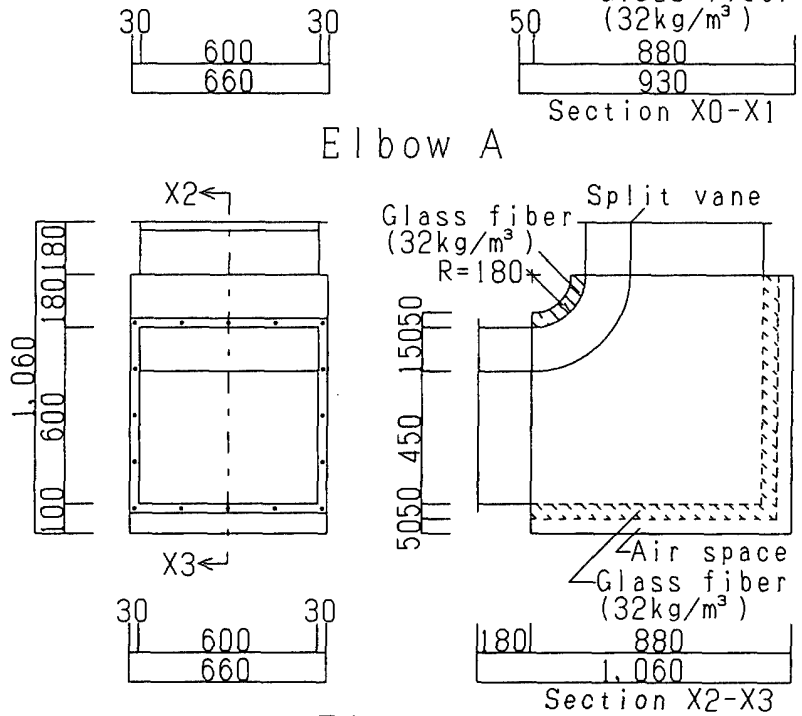

Elbow As

図 1 消音エルポ
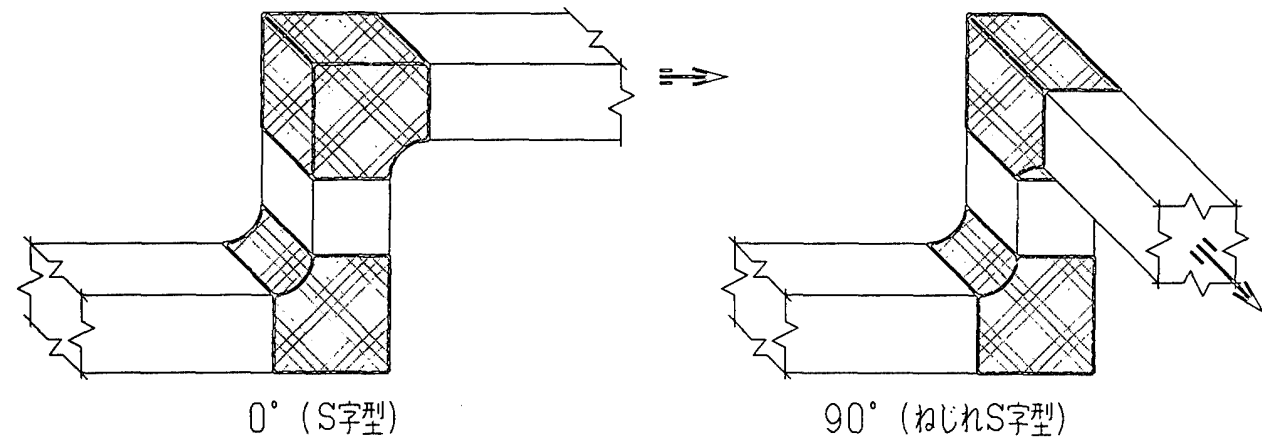

$90^{\circ}$ (ねじい字型)

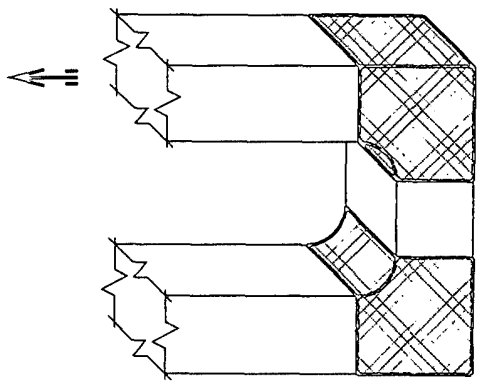

$180^{\circ}$ (U字型) 


\section{4. 実験結果および考察}

\section{4 - 1 . 単体消音エルボ}

単体消音エルボの挿入損失を図 4 に示す。63 および $125 \mathrm{~Hz}$ 帯域の 低音域では Elbow A およびAs ともに，ほぼ等しい值を示す。250Hz 帯域以上の中〜高音域では Elbow A の挿入損失が Elbow As のそ执よ りも 2〜 5dB 程度大きい。これはElbow As のスプリッタ・ベーンによ り一部の中〜高音域があまり吸音されずにエルボ内を通過するため と考えられる。

(a)

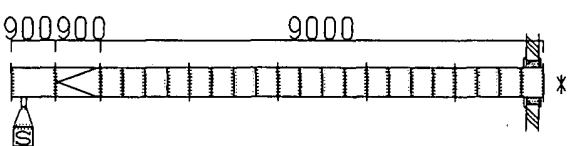
5400

(c)

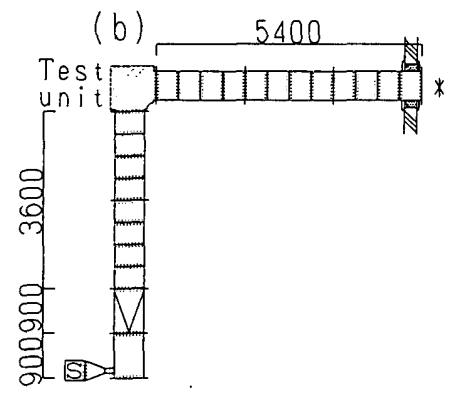

900900200

10800

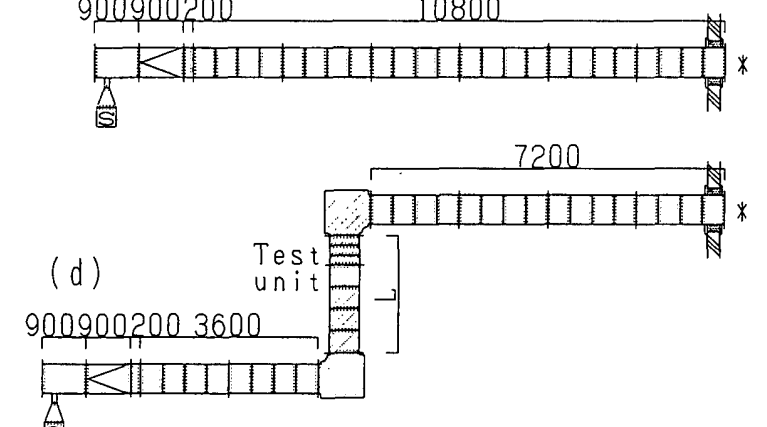
:

(e)

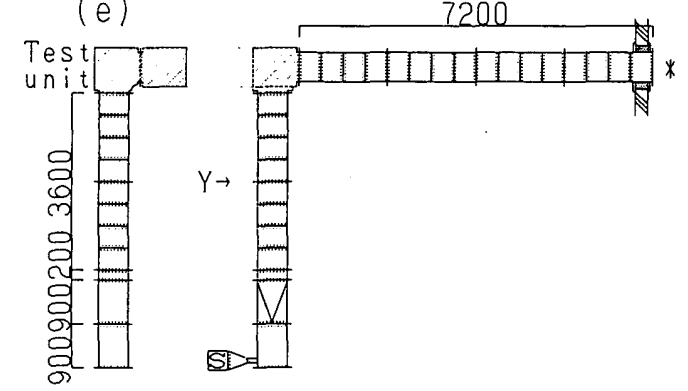

Y sideview

$(f)$

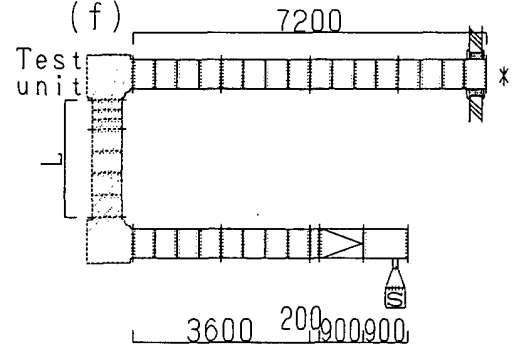

S: Speaker

L: Duct length between two elbow's

*: Reverberation room

図 3 実騃装置

\section{4-2. 連続消音エルボ}

接続方向 $0^{\circ}$ で連続消音エルボ $\mathrm{AA}$ ，AsA および AAs の挿入損失を 使用されている 2 つの単体消音エルボの挿入損失を加算した值とと もにそれぞれ図 5,6 および7に示す。いずれのダクト系においても 挿入損失の測定值は 63 および $125 \mathrm{~Hz}$ 帯域で $10 \mathrm{~dB}$ 前後, $250 \mathrm{~Hz}$ 帯域 以上で $20 \mathrm{~dB}$ 前後から $25 \mathrm{~dB}$ の間でフラットな特性を示す。

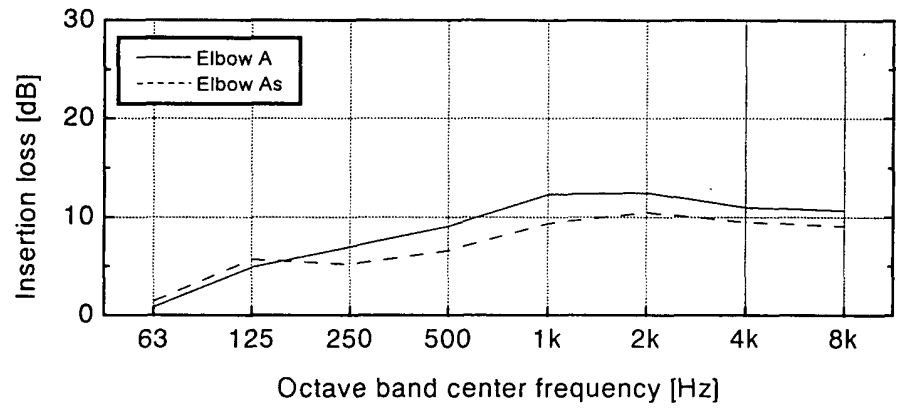

図4単体消音エルボの挿入損失

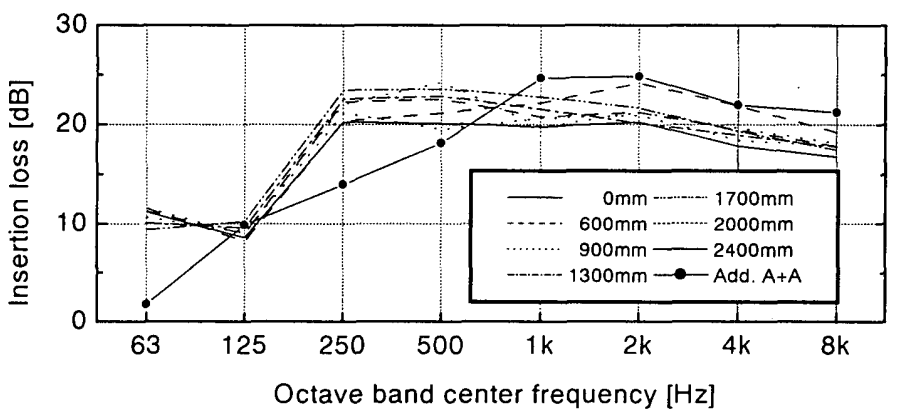

図5連続消音エルボ0"-AAの挿入損失

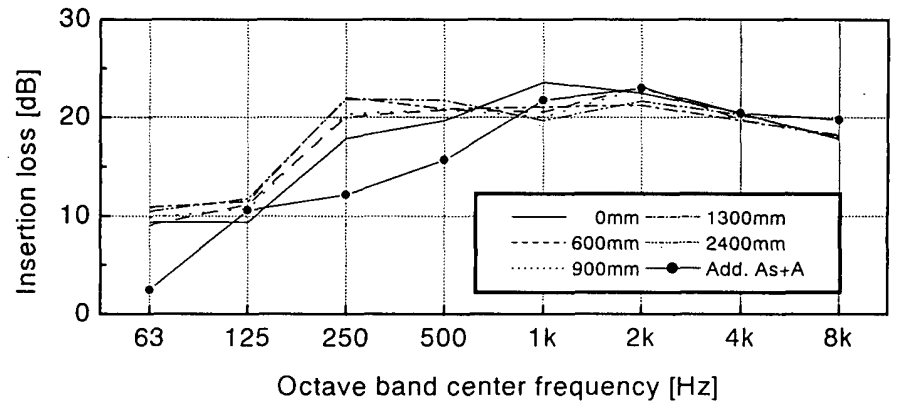

図6連続消音エルボ 0 "-AsAの挿入損失

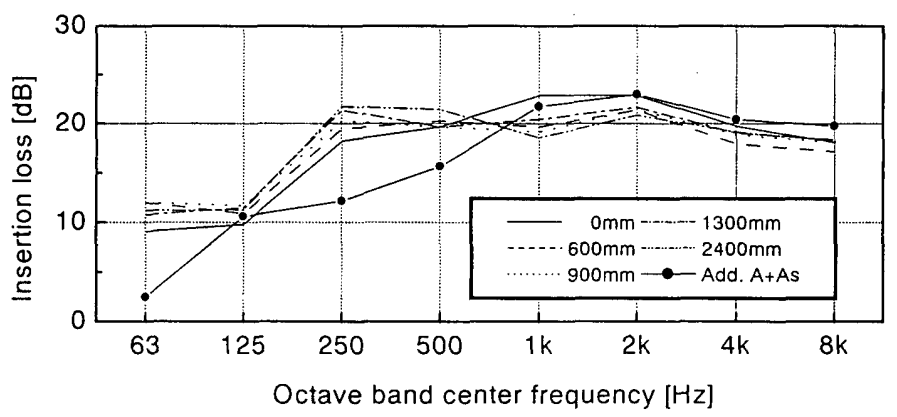

図7連続消音エルボ0"-AAsの挿入損失 
$1 \mathrm{kHz}$ 帯域以上で測定值と加算值とを比較すると，連続消音エルボ $\mathrm{AA}$ ではエルボ間距離 $600 \mathrm{~mm}$ を除けば, 前者が後者より $3 \sim 5 \mathrm{~dB}$ 程度 小さいが，スプリッタ・ベーン付きエルボ As を用いた連続消音エル ボAsA およびAAsでは，いずれも両者の差は小さい。

すべての組合せにおいて $125 \mathrm{~Hz}$ 帯域を除く $500 \mathrm{~Hz}$ 帯域以下での測 定值は，加算值より 5 8dB 大きく，125Hz 帯域での両者の值はほぼ 等しい。

接続方向 $180^{\circ}$ で連続消音エルボ AA，AsA およびAAs の挿入損失 を使用されている2つの単体消音エルボの㨂入損失を加算した值と ともにそれぞれ図 8，9 および10 に示す。

$63 \mathrm{~Hz}$ 帯域では, 連続消音エルボ A.A の挿入損失は接続方向 $0^{\circ}$ の場 合と異なり，5〜14dB の範聿でエルボ間距離により值が分散する。 また，スプリッタ・ベーン付きエルボ As を用いた連続消音エルボ AsA およびAAs の挿入損失は，一部を除き $10 \mathrm{~dB}$ 前後を示す。125Hz 帯域では, 連続消音エルボ $\mathrm{AA}$ の挿入損失は $10 \mathrm{~dB}$ 前後を示し, 連続 消音エルボAsA およびAAs のそれらは $12 \mathrm{~dB}$ 前後を示す。連続消音工 ルボ AA の挿入損失はエルボ間距離 $0 \mathrm{~mm}$ を除けば, 250〜 $4 \mathrm{kHz}$ 帯域で

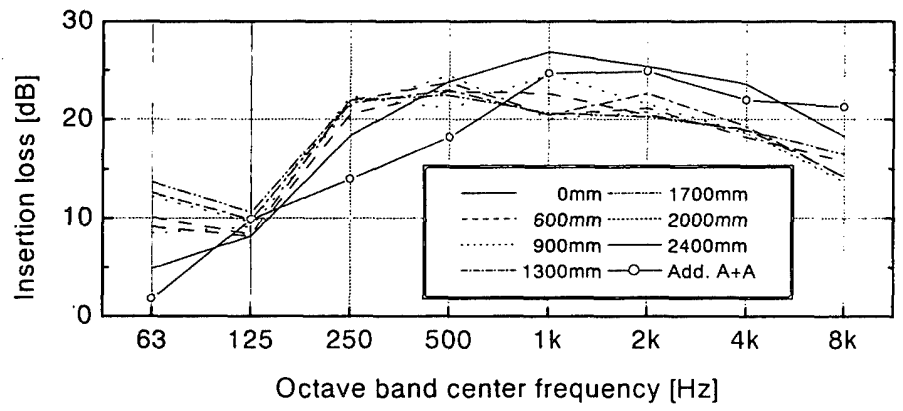

図8 連続消音エルボ $180^{\prime \prime}-\mathrm{AA}$ の挿入損失

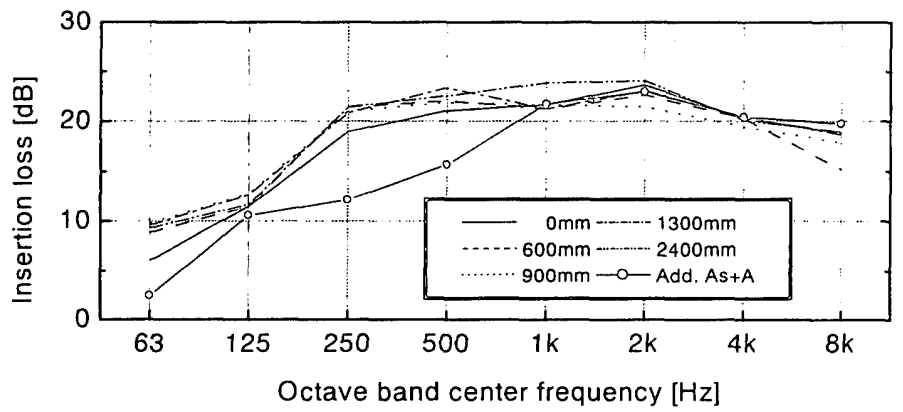

図9連続消音エルボ180"-AsAの挿入損失

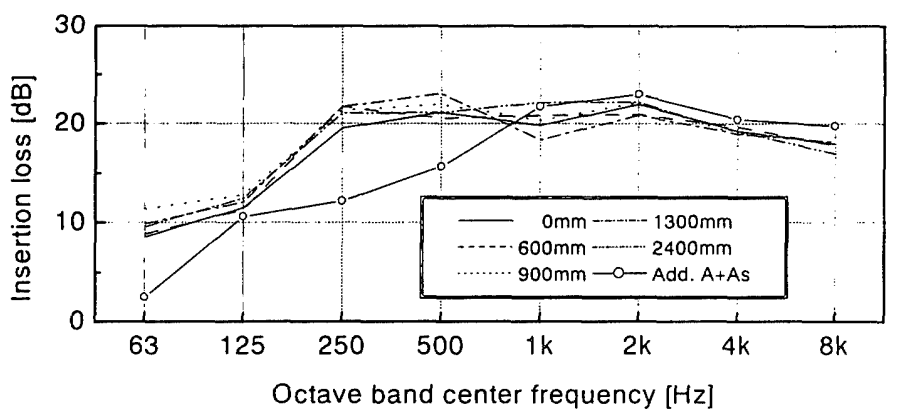

図10 連続消音エルボ $180^{\circ}-\mathrm{AAs}$ の挿入損失
は, $20 \mathrm{~dB}$ 前後から $25 \mathrm{~dB}$ の間でフラットな特性を示し, $8 \mathrm{kHz}$ 帯域で は， $15 \mathrm{~dB}$ 前後を示す。スプリッタ・ベーン付きエルボ As を用いた 連続消音エルボ AsA および AAs の挿入損失は, $250 \mathrm{~Hz}$ 帯域以上で一 部を除き， $20 \mathrm{~dB}$ 前後から $25 \mathrm{~dB}$ の間でフラットな特性を示す。

$1 \mathrm{kHz}$ 帯域以上で測定值と加算值とを比較すると，連続消音エルボ AA ではエルボ間距離 $0 \mathrm{~mm}$ を除けば, 前者の方が後者よりも小さく, その差は大きいところで $5 \mathrm{~dB}$ 程度ある。しかし，スプリッタ・ベー ン付きエルボAs を用いた連続消音エルボAsAおよびAs では, 両者 の差は小さい。

また，すべての組合せにおいて $125 \mathrm{~Hz}$ 帯域を除く $500 \mathrm{~Hz}$ 帯域以下 の低〜中音域では, 測定値の方が加算値より $5 \sim 8 \mathrm{~dB}$ 大きく, $125 \mathrm{~Hz}$ 帯域での両者の值は $1 \mathrm{~dB}$ 前後の差を示す。

接続方向 $0^{\circ}$ および $180^{\circ}$ いずれにおいても, 全体的に見て, 平面 波理論の適用限界 $\mathrm{a}=\lambda / 2(\mathrm{a}=600 \mathrm{~mm})$ の周波数 $\mathrm{f}=283 \mathrm{~Hz}$ を含む $250 \mathrm{~Hz}$ 帯域の 2 倍である $500 \mathrm{~Hz}$ 帯域までの測定值と加算値との特性は異な り，1 kHz 帯域以上では，両者はフラットな特性を示す。

エルボ間距離 $0 \mathrm{~mm}$ の各組合せによる挿入損失を使用されている 2

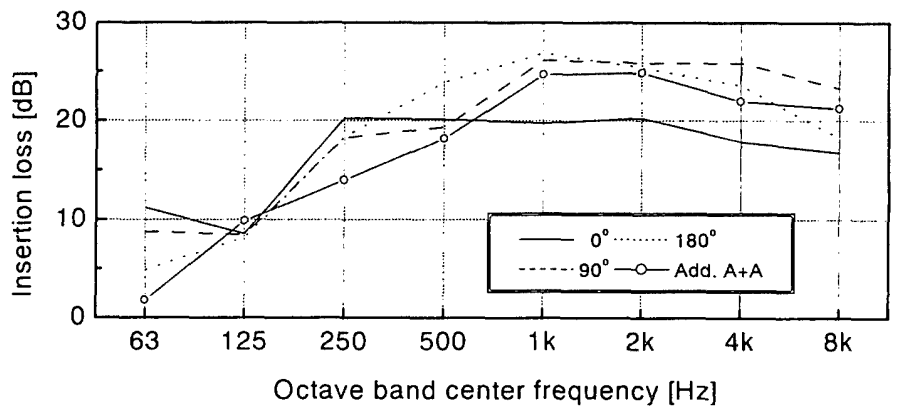

図11 連続消音エルボAA-0の挿入損失

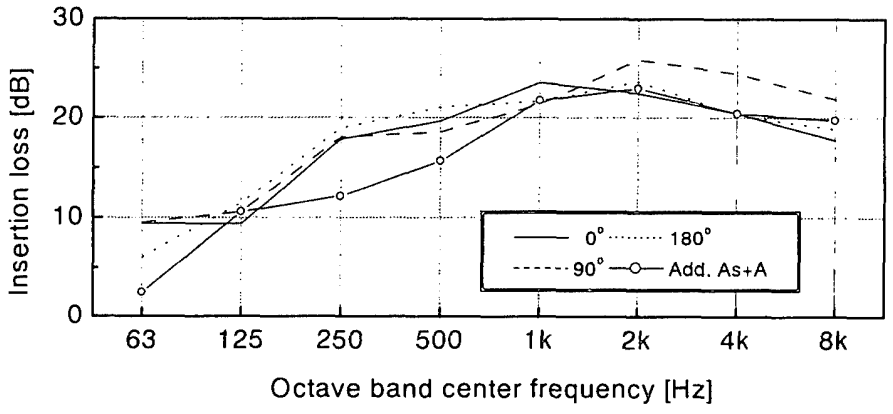

図12 連続消音エルボAsA-0の挿入損失

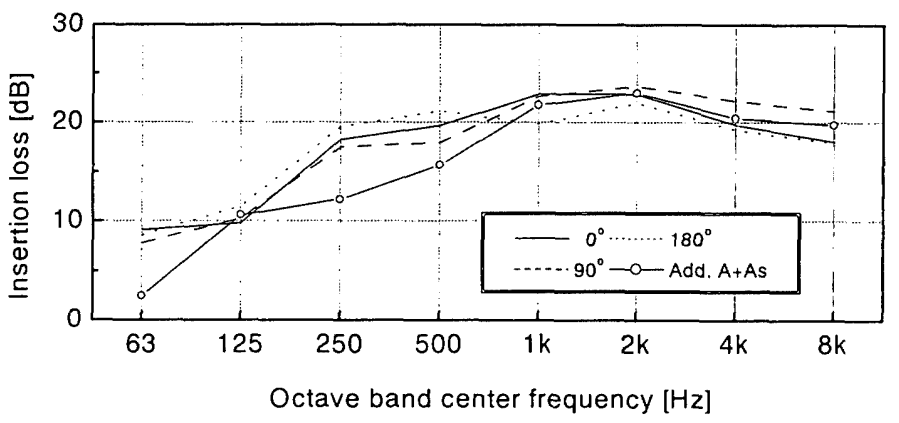

図13 連続消音エルボAAs-0の挿入損失 
つの単体消音エルボの挿入損失を加算した值とともにそれぞれ図

11,12 および 13 に示す。

連続消音エルボ AA の挿入椇失は，スプリッタ・ベーン付きエルボ As を用いた連続消音エルボAsA およびAAs のそれらと比較して，全 体的に見ると，いずれの周波数においても $0^{\circ} ， 90^{\circ}$ および $180^{\circ}$ の 3 方向における測定值の差が大きい。また， $90^{\circ}-\mathrm{AsA}-0$ における測 定值は, $2 \mathrm{kHz}$ 帯域以上の高音域で他の接続方向のそ扎らより3〜 $\mathrm{AB}$ 大きい。

$90^{\circ}$ における挿入損失の測定値と加算値とを比較すると，いずれ においても $125 \mathrm{~Hz}$ 帯域を除く全ての周波数帯域で前者は後者より大 きい值を示す。

今回の測定結果によれば，連続消音エルボの設計において2つの 単体消音エルボの挿入損失を加算して用いる場台, $1 \mathrm{kHz}$ 帯域以上で は全体的に測定值が加算值より小さいため危険側になり，125Hz 帯 域を除く $500 \mathrm{~Hz}$ 帯域以下では測定值が加算值に比べて大きいため安 全側になる結果が得ら扎た。また，スプリッタ・ベーン付きエルボ を用いた場合, $1 \mathrm{kHz}$ 帯域以上では測定値と加算值との差が小さくな る。

\section{5. 結論}

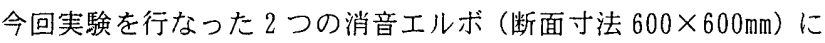
よる連続消音エルボの特徵を以下にまとめる。

1) 連続消音エルボの挿入損失は, $63 \sim 125 \mathrm{~Hz}$ 帯域で約 $10 \mathrm{~dB}, 250 \mathrm{~Hz}$ 帯域以上の中〜高音域では $15 \mathrm{~dB}$ 前後から $25 \mathrm{~dB}$ 前後の間を示す。

2） $0^{\circ} ， 90^{\circ}$ および $180^{\circ}$ に接続方向を変化させた場合，スプリッ タ・ベーンのないエルボのみを用いた連続消音エルボにおいて は, 全周波数帯域において 3 方向の挿入損失の差は大きいが, スプリッタ・ベーン付きエルボを用いた連続消音エルボにおい てのそれらは小さい。

3）接続方向 $0^{\circ}$ および $180^{\circ}$ いずれにおいても，全体的に見て， 平面波理論の適用限界 $\mathrm{a}=\lambda / 2(\mathrm{a}=600 \mathrm{~mm})$ の周波数 $\mathrm{f}=283 \mathrm{~Hz}$ を 含む $250 \mathrm{~Hz}$ 帯域の 2 倍である $500 \mathrm{~Hz}$ 帯域までの測定值と加算値 との特性は異なり，1 kHz 帯域以上では，両者はフラットな特性 を示す。

4) $125 \mathrm{~Hz}$ 帯域を除く500Hz 帯域以下においては, スプリッタ・ベ ーンの有無によらず，連続消音エルボの挿入損失の測定值は加 算值より大きく, $125 \mathrm{~Hz}$ 帯域での測定值は加算值とほぼ等しい。
5） $1 \mathrm{kHz}$ 帯域以上において，スプリッタ・ベーンのないエルボのみ を用いた連続消音エルボの挿入損失の測定值は，一部を除き加 算値より小さい。また、スプリッタ・ベーン付きエルボを用い た連続消音エルボの挿入損失の測定値と加算值との差は、スプ リッタ・ベーンのないエルボのみを用いたそれらより小さくな る。

今後, 連続消音エルボの消音設計用デー夕を整備するにあたり，消 音エルボの種類や断面寸法，接続距離が異なる場合について同様な 測定を行い，また，気流による発生馶音についても検討する必要が ある。

謝 辞

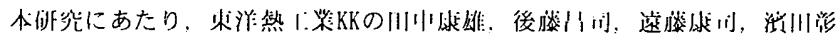

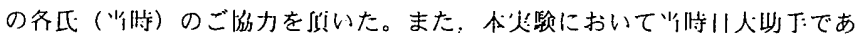

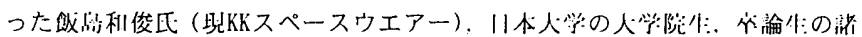

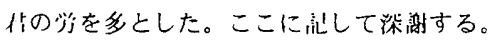

\section{参考文献}

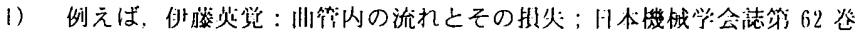
筑 490 今, pp46-55, 1959.11

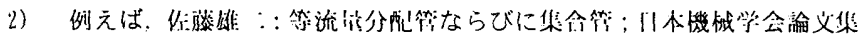

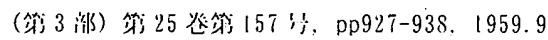

3) 例えば, H.K.R.Lipperl：A IEH YETHOD OF COMPETISG ACOCSTICAL FILTERS; ACLSTICA V0I.4, Y0. 4, pp411-420, 1954.

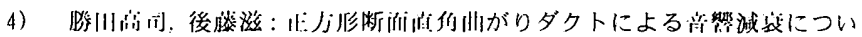

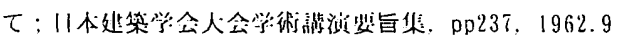

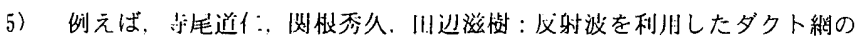

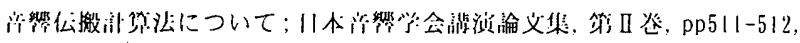
1980.9

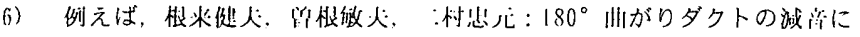

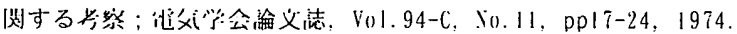

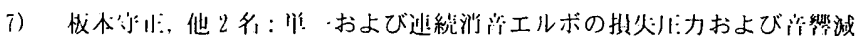

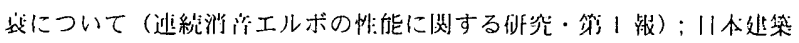

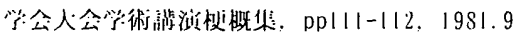

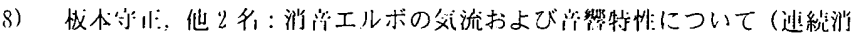

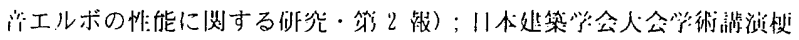
概集，pp181-182，1982，10

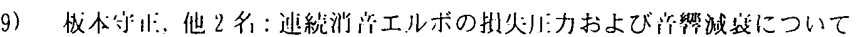

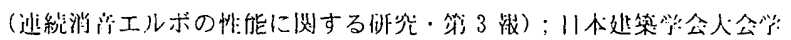

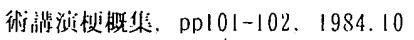

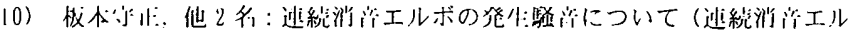

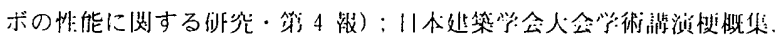
pp103-104, 1984.10 